\title{
Energy Consumption in the Municipal Water Supply Sector in the Kingdom of Bahrain
}

\author{
Maryam Marzooq ${ }^{1,2}$, Maha Alsabbagh ${ }^{2 *}$, Waleed Al-Zubari ${ }^{2}$ \\ ${ }^{1}$ Electricity and Water Authority, Manama, Kingdom of Bahrain \\ ${ }^{2}$ Department of Natural Resources and Environment, Arabian Gulf University, Manama, Kingdom of Bahrain \\ Email: *mahamw@agu.edu.bh
}

How to cite this paper: Marzooq, M., Alsabbagh, M. and Al-Zubari, W. (2018) Energy Consumption in the Municipal Water Supply Sector in the Kingdom of Bahrain. Computational Water, Energy, and Environmental Engineering, 7, 95-110. https://doi.org/10.4236/cweee.2018.73006

Received: April 22, 2018

Accepted: June 29, 2018

Published: July 2, 2018

Copyright $\odot 2018$ by authors and Scientific Research Publishing Inc. This work is licensed under the Creative Commons Attribution International License (CC BY 4.0).

http://creativecommons.org/licenses/by/4.0/

(c) (i) Open Access

\begin{abstract}
Water-energy nexus is an emerging issue that receives considerable attention in the world in general and in the Gulf Cooperation Council (GCC) countries in particular. The GCC countries depend mainly on energy generated from fossil fuels to produce drinking water. Yet, the amount of water-related energy use in Bahrain remains unexplored. This study aims to quantify the amount of energy used in the water supply cycle for the first time in Bahrain using quantitative methods. A bottom-up approach for data collection was adopted where data for the three main stages of the water supply in Bahrain: water production, water transmission, and water distribution were collected. Results show that the water production stage consumes about $97 \%$ of the total energy consumption in the water supply sector, followed by water transmission $(2.9 \%)$ and water distribution $(0.1 \%)$. Comparisons conducted with best practices in the world show that water desalination plants in Bahrain consume relatively high amounts of energy to produce water based on the desalination technology used. This study calls for focusing on the production stage in achieving energy efficiency since it is the largest consumer and where losses are occurring based on the benchmarking. This study also recommends investigating the share of electricity and thermal energy consumed in the water supply cycle in Bahrain in addition to the wastewater treatment sector. This is imperative to provide a holistic overview of the water-related energy use in Bahrain.
\end{abstract}

\section{Keywords}

Water-Energy Nexus, Specific Electric Energy Use, Water Distribution, Water Production, Water Transmission

\section{Introduction}

The water-energy nexus has emerged as one of the most important issues in the 
world. Both of the water and energy sectors depend on each other in terms of supply and use. Throughout the lifecycle of water, an intensive amount of energy is used. The same thing applies to the lifecycle of energy where water is required at the different stages of the energy production [1].

Various factors contribute to shaping the relationship between water and energy. The list of factors includes population growth, economic development and consumption patterns [2]. Nonetheless, the water cycle is considered as an energy-intensive process [3]. The footprint of energy in the water production phase is considerably high in comparison with other phases in the water lifecycle because it depends mainly on energy consumption [4]. Water transmission over large distances in addition to water distribution to the end users also comes with a noticeable energy price tag [5].

The nexus of water and energy is now becoming a dominant crucial point of interest, both in terms of problem identification and in seeking trans-disciplinary and trans-sectorial solutions. Identifying the linkages, dynamics, stakeholders, and potential governance options is critical to facilitate collaboration between sectors and countries in the case of shared natural resources [5]. The nexus can be described in terms of efficiency as the quantity of water required to generate one unit of energy and the amount of energy used to produce a single unit of water [6].

Water production in the Gulf Cooperation Council (GCC) countries relies heavily on water desalination as the only option available to provide drinking water. There are two main desalination technologies: thermal evaporation and membrane separation [7]. Commercially, three technologies are widely used for water desalination; these are Multi-Stage Flashing (MSF), Reverse Osmosis (RO), and Multi-Effect Distillation (MED). The MSF and MED technologies are thermal technologies, whereas the RO is a membrane separation technology. The MSF desalination technology is considered as the baseline of desalination technologies being established in the 1950s. In terms of energy use, the MED technology is more efficient than MSF [8]. However, the RO is considered as the most energy efficient desalination technology where its primary energy consumption is less than MED and MSF by 5 to 6 times [9]. Nonetheless, no specific desalination technology can be recommended for the GCC countries. The selection of desalination technologies depends on several factors including the salinity of the water, whether electricity is going to be generated, and availability of fuels.

In general, desalination is an energy-intensive process. Desalination is estimated to consume $5 \%-12 \%$ of total electricity consumption in the GCC [10]. Thus, the water-energy nexus was found to be positively correlated with water scarcity in the GCC countries [3]. This correlation is especially true for the GCC where desalination is considered as the only option to provide drinking water.

Energy is also consumed in water transmission and water distribution, and specifically in booster pumping stations. Booster pumping stations include pumps, valves and pipes, where they boost the pressure in the water distribution 
network to transfer the water from lower points to higher ones [11]. Energy is consumed in pumping water into the water distribution network. Losses of energy in this stage are expected to be 30\% [12]. Inefficient pumping stations with poor design result in energy loss in the water supply network [13]. Energy efficiency can be achieved by improving the design of the pumping stations and installing variable speed drives to pumps and operating them efficiently.

Situated in an extremely arid environment, Bahrain has scarce water resources and will be one of the top 33 water stressed countries in the world by 2040 . Water stress in Bahrain is driven mainly by the rapid growth of population in addition to the geography and climate of the county [2]. To meet its drinking water requirements, Bahrain depends on desalination, which is costly, energy intensive, and detrimental to the environment [14].

Understanding and quantification of the water-energy nexus in Bahrain is of extreme importance and is a pre-requisite for any energy efficiency programs in the water sector. Future projections show an average annual increase of $3.8 \%$ in the water demand by 2035 compared to 2010 [15]. This implies the need for more energy to ensure meeting these anticipated water demands. However, Bahrain has limited fossil fuel resources and are depleting while the renewable energy sources make very minimal share of the total energy supply [16]. Furthermore, the increase of fossil fuels consumption results in an increase in the Greenhouse Gas (GHG) emissions, which contributes to climate change.

Considering the interlink ages between water and energy, saving water means saving energy as well as minimizing environmental externalities [17]. Thus, saving water contributes to the achievement of the sixth goal of the Sustainable Development Goals (SDGs) on sustainable water management, which entails increasing water-use efficiency in all sectors. It also contributes to the achievement of SDG 7 on sustainable energy through improving energy efficiency, which ultimately contributes to the achievement of the thirteenth SDG on taking action to combat climate change.

Understanding the water-energy nexus in Bahrain also contributes to achieving Bahrain energy efficiency target set at $6 \%$ by 2025. Furthermore, it offers opportunity for climate change mitigation and consequently to comply with Bahrain's commitments under the Paris Agreement, i.e., nationally determined Commitments (NDCs).

There are few studies [14] [15] that tackle the water-energy nexus in Bahrain while projecting the costs and impacts of future water demand. However, the energy consumption figures were mainly generic where no specific energy consumption figures were provided for each desalination plant.

Accordingly, this paper aims to bridge the knowledge gap related to the water-energy nexus in Bahrain. Specifically, it aims at quantifying the amount of energy used in the three stages of the water supply cycle, production, transmission and distribution) for the first time for Bahrain, and identifying Bahrain standing compared to best practice in energy efficiency in the world.

This paper consists of five sections. The next section presents the municipal 
water supply cycle and its main components in Bahrain with special focus on the desalination plants. The third section elaborates on the methodology applied in the quantification of the energy input in the water cycle, while section four presents the results and their analysis, followed the main conclusion and recommendations section.

\section{The National Context}

There are three main stages for the water supply cycle in Bahrain: water production (mainly water desalination with minor groundwater pumping for blending), water transmission, and water distribution. The Electricity and Water Authority (EWA) is the utility responsible for the provision of municipal water supply in Bahrain, and is fully responsible for water transmission and distribution. As for water production, the private sector contributes to the provision of drinking water supply by three desalination plants of the five plants in the country. Water produced by the private sector is purchased by EWA through a long-term contract.

\subsection{Water Production}

Water desalination plants in Bahrain vary in terms of year of operation, ownership, source of water, products, desalination technologies, and production capacity. Details of the five operating desalination plants are provided in Table 1 and the following sections.

\subsubsection{Sitra Power and Water Station}

Sitra Power and Water Station is a plant that produces both electrical power and water. The plant is the oldest water production plant in Bahrain and is owned by EWA. There are three phases in Sitra desalination plant. The first phase was commissioned in 1975 and consists of two MSF units (Distiller 1A and 1B in Figure 1). Each of the two MSF units produces 2.5 Million Gallon PerDay (MGPD). The second phase was commissioned in 1984 and has one MSF unit (Distiller 5 in Figure 1) producing 5 MGPD. The third phase was commissioned in 1985 and consists of three MSF units (Distiller 2, 3 and 4 in Figure 1) producing $5 \mathrm{MGPD}$ each at $90^{\circ} \mathrm{C}$ or $6.8 \mathrm{MGPD}$ at $110^{\circ} \mathrm{C}$.

\subsubsection{Ras Abu Jarjur}

Ras Abu Jarjur is a reverse osmosis desalination plant that uses brackish groundwater extracted using submersible pumps from 19 wells under the ground at depth of $65 \mathrm{~m}$ (Figure 2 and Figure 3). The plant is owned by EWA and was commissioned in 1984. The RO desalination plant has a water production capacity of 16.5 MGPD.

\subsubsection{Al Dur Company}

The Al Dur plant started operation in 2012 and cost around USD 2.1 billion. The plant is located on the south west coast of Bahrain and produces 1234 megawatts (MW) of power and $48 \mathrm{MGPD}$. This plant utilizes RO technology for seawater 
Table 1. Water desalination plants in Bahrain.

\begin{tabular}{|c|c|c|c|c|c|}
\hline Plants & Sitra & Ras Abu Jarjur & Hidd & ALBA & Al Dur \\
\hline $\begin{array}{c}\text { Year of } \\
\text { operation }\end{array}$ & 1975 & 1984 & 1999 & 2001 & 2012 \\
\hline Ownership & Government & Government & Private sector & Private sector & Private sector \\
\hline Source of water & Sea water & Brackish ground water & Sea water & Sea water & Sea water \\
\hline Products & $\begin{array}{l}\text { Desalinated water, } \\
\text { power }\end{array}$ & Desalinated water & $\begin{array}{l}\text { Desalinated water, } \\
\text { power }\end{array}$ & $\begin{array}{l}\text { Desalinated water, calcined } \\
\text { petroleum carbon }\end{array}$ & $\begin{array}{c}\text { Desalinated water, } \\
\text { power }\end{array}$ \\
\hline $\begin{array}{l}\text { Desalination } \\
\text { technologies }\end{array}$ & MSF & RO & MSF, MED & MED & RO \\
\hline $\begin{array}{c}\text { Production capacity } \\
\text { (MGPD) }\end{array}$ & 25 & 16.5 & 90 & 9.5 & 48 \\
\hline
\end{tabular}

Notes: MSF is multi-stage flashing, RO is reverse osmosis, MED is multi-effect distillation, MGPD is million gallon per day.

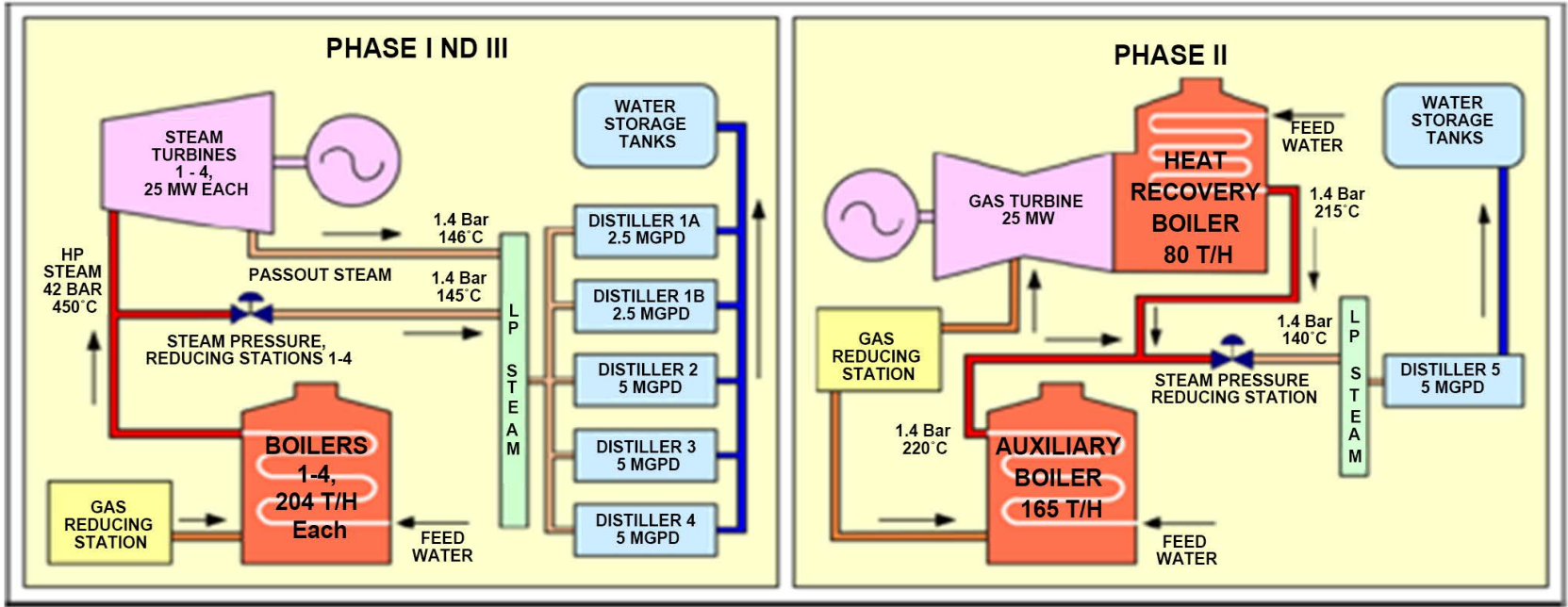

Figure 1. Block diagram for sitra power and water station [18].

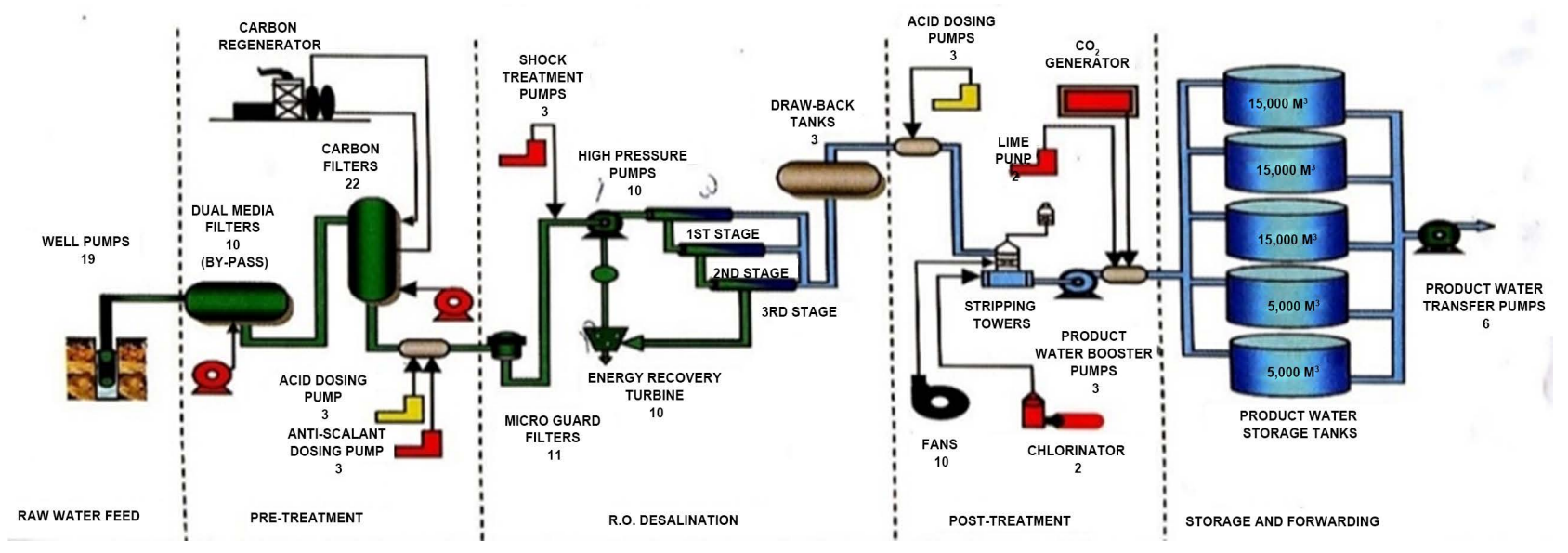

Figure 2. Simplified schematic of ras abu jarjur desalination plant [19].

desalination. EWA is the sole off-taker of the plant output as stipulated in the 25-year Power and Water Purchase Agreement. 


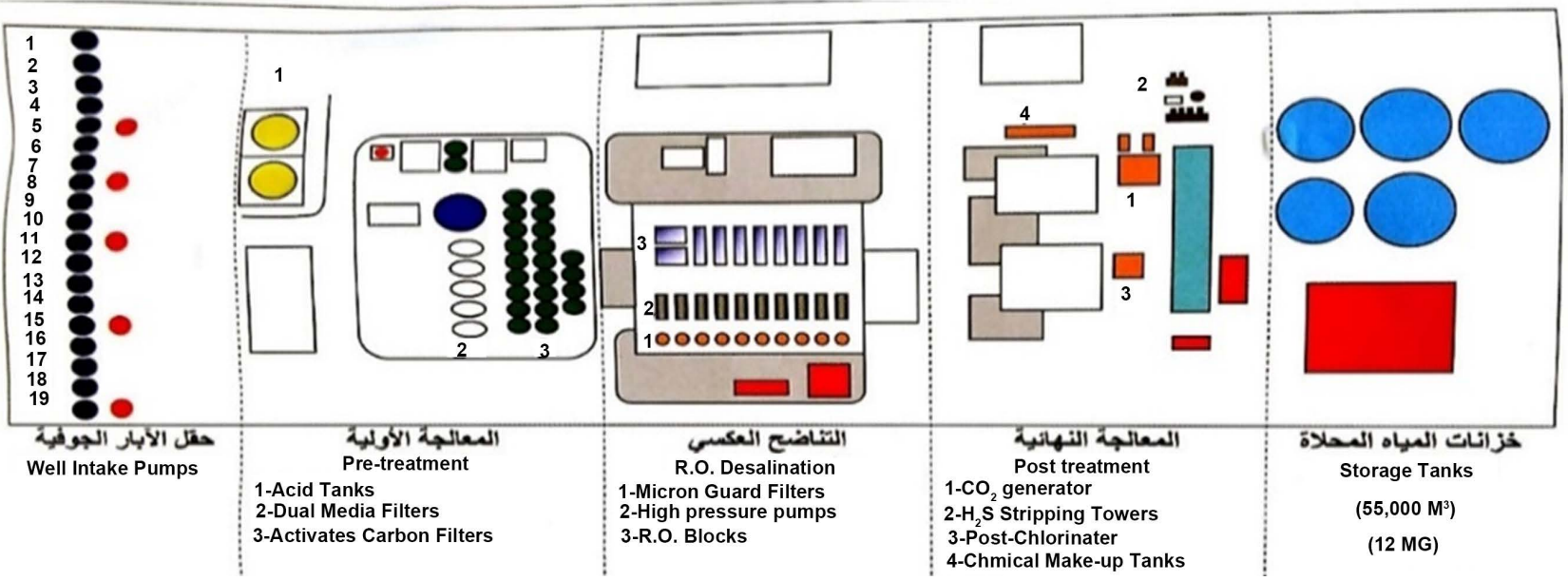

Figure 3. Procedures of water production in ras abu jarjur plant [19].

\subsubsection{ALBA}

Aluminium Bahrain (ALBA) is a company that produces aluminum and has its own desalination plant. There are four MED water desalination units in ALBA with a total capacity of 9.5 MGPD of water. There are two water storage tanks in ALBA; the first one is for ALBA's internal consumption, and the second is for EWA. A pipeline goes out from the second storage tank to Sitra blending station which is owned by EWA. Around $70 \%$ of the produced drinking water is purchased by EWA and other external customers, whilst the remainder is used for ALBA's in-house consumption (Figure 4).

\subsubsection{The Hidd Power Company}

The Hidd Power Company (HPC) was comissioned in 1999. The HPC produces 90 MGPD of drinking water and $1000 \mathrm{MW}$ of power daily. Both of the MSF and MED desalination technologies are used in the HPC. The plant is owned by the private sector and has three phases. The first phase has a power capacity of 276 MW and water capacity of $30 \mathrm{MGPD}$. The second phase has power capacity of $729 \mathrm{MW}$ and the third phase has water capacity of 60 MGPD. The first phase applies the MSF desalination technology, and the third phase applies the MED technology (Figure 5).

\subsection{Water Transmission}

Water transmission is the responsibility of Water Transmission Directorate (WTD) in EWA. WTD is mainly responsible for receiving the produced water from the desalination plants and then transferring it to the water distribution network in good quality ensuring compliance with the GCC/Bahrain drinking water standards GSO-149/2014 and the latest WHO guidelines for drinking water quality. The responsibility of ground water abstraction is under WTD as well so as to ensure covering any shortage in the desalinated water by blending the produced water with the groundwater if needed. Energy is used in the WTD network to pump water from the production plants to transmission networks and then from the transmission network to the distribution network. 


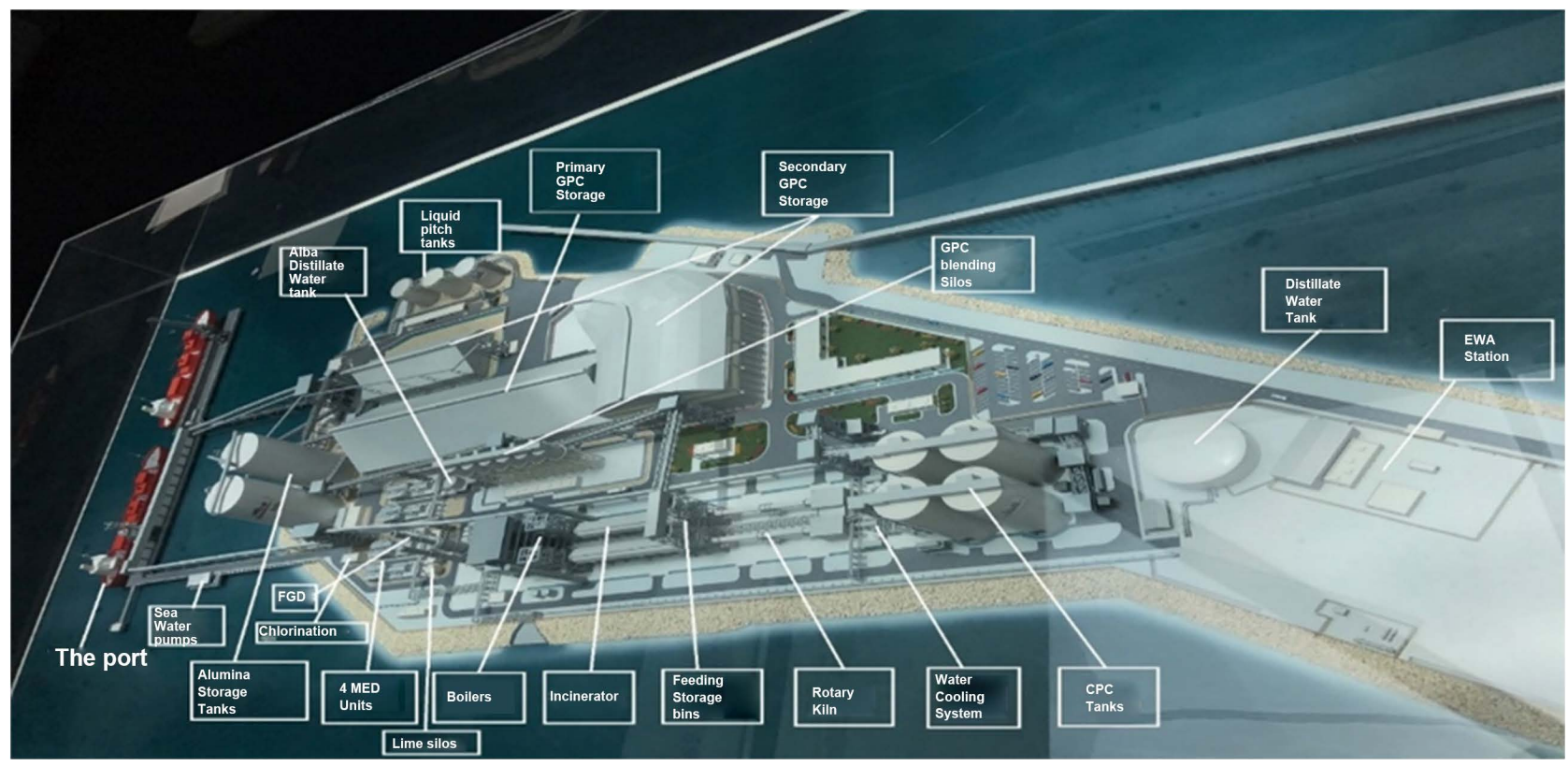

Figure 4. Top view of ALBA water desalination (the photo is taken by authors during a visit to ALBA).
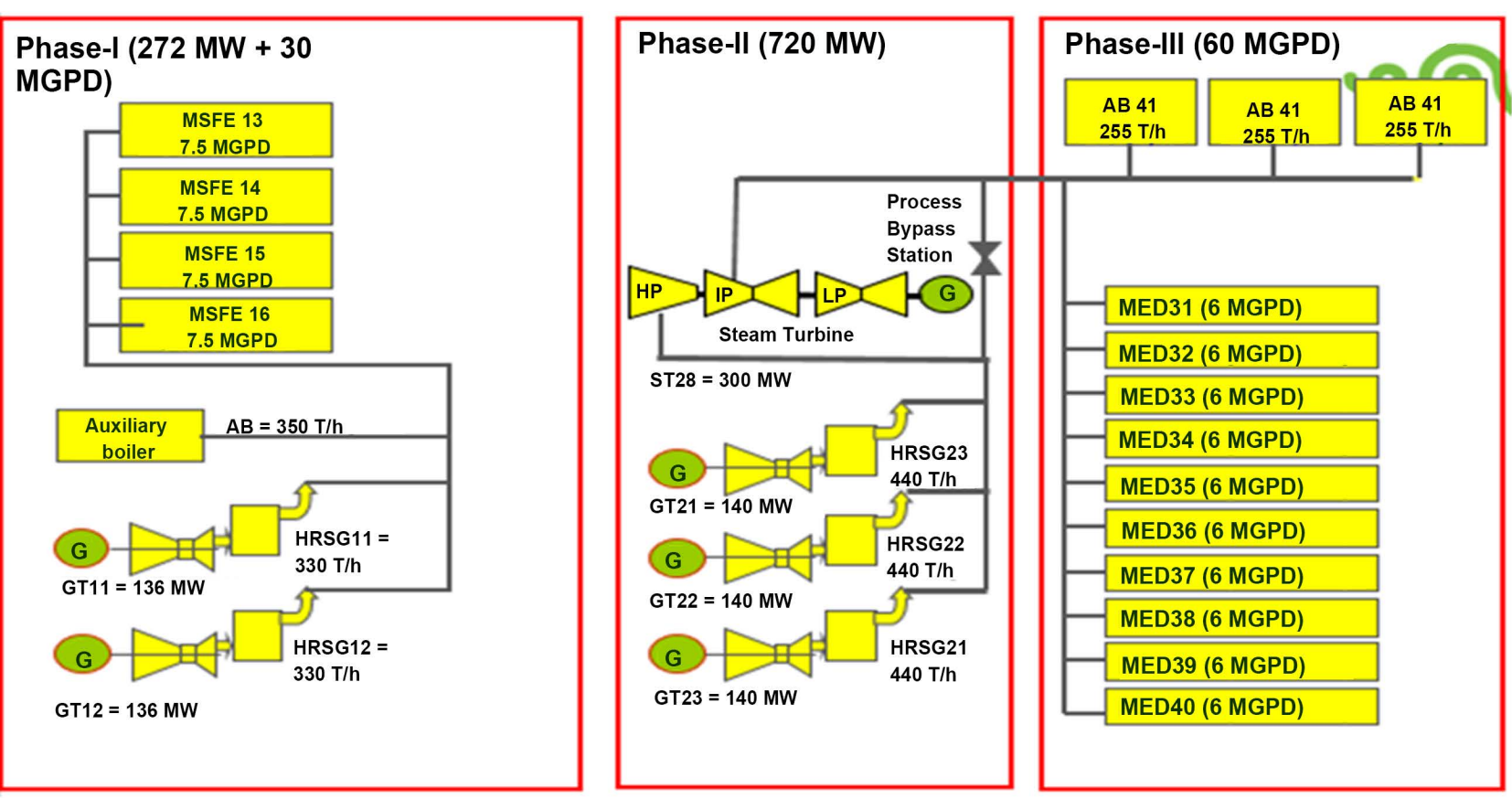

Figure 5. Phases of water and power production in HPC [20].

\subsection{Water Distribution}

The Water Distribution Directorate (WDD) in EWA is responsible for providing customers with water. There are six working booster pump stations in the water distribution network located in different areas of Bahrain. In each booster pumping station, there are two motors and two pumps. Each motor and pump are integrated so that they work together. The pumps in each booster pumping station work interchangeably with electricity being the energy source. 


\section{Methodology}

To achieve the study's objectives, a quantitative bottom-up approach was applied to quantify the electricity consumption in the water supply cycle in Bahrain. This is made by the following steps:

1) The main stages of the water supply cycle in Bahrain were identified through review of EWA reports and face-to-face interviews conducted with the concerned policymakers and experts. Three main stages were identified as elaborated above: water production, water transmission and water distribution.

2) The sources for electricity use within the three stages of the water supply cycle were identified through interviews and field visits. This step revealed that five desalination plants form the first stage, twenty-seven pumping stations within the transmission stage, and six working booster pumping stations within the third stage.

3) Technical specifications (rated power in particular) related to the main electricity consumers in the desalination plants and transmission pumping stations were obtained. As for the distribution pumping stations, a clamp meter was used to calculate the current and the voltage in those sites in 2017 (Figure 6). Accordingly, energy consumption was calculated using the following equations:

$$
\begin{gathered}
\text { Power }(\mathrm{kW})=\text { Voltage }(\text { Volts }) * \text { Curren }(\text { Ampere }) \\
\text { Energy }(\mathrm{kWh})=\text { Power }(\mathrm{kW}) * \operatorname{Time}(\text { working hours }-h)
\end{gathered}
$$

It is worthy to note that quantifying energy consumption based on the technical specification was applied for all desalination plants except for ALBA. Electricity consumption bills for ALBA's petroleum coke calciner and seawater desalination plant were obtained and $48 \%$ of the electricity was assumed to have been consumed in the desalination plant as advised by the concerned operators.

4) The amount of municipal water produced was obtained from EWA. The quantity of water being pumped to the booster pumping stations was calculated

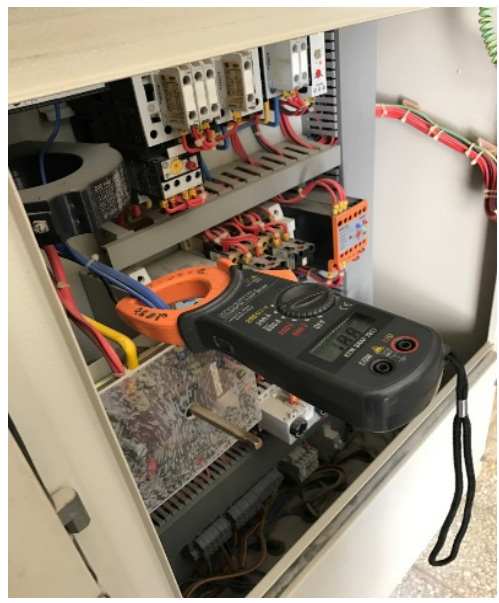

Figure 6. Clamp meter used to measure the voltage and current (the photo is taken by authors). 
based on the diameter of the inlet pipe (i.e., $150 \mathrm{~mm}$ for all pipes) and assuming a velocity range of 0.6 and 1.2 meter/second. Equation number 3 was used to quantify the amount of water being pumped as follows:

$$
\begin{aligned}
\text { Quantity of water }\left(\mathrm{m}^{3} / \mathrm{s}\right)= & (\pi / 4) * \text { Diameter of the pipe }(\mathrm{mm})^{2} \\
& * \text { velocity }(\text { meter/second })
\end{aligned}
$$

5) Specific electric energy use was calculated by dividing the amount of electricity consumption in kilowatt-hour $(\mathrm{kWh})$ by the amount of water produced per day in cubic meters $\left(\mathrm{m}^{3}\right)$.

6) Relevant literature was reviewed for best practices and was used to benchmark the results obtained from this research.

7) Based on the analysis and evaluation of the energy values in the water cycle a number of recommendations were provided.

\section{Results and Discussion}

This section presents the calculation results concerning the electricity consumption and specific electric energy use in details for each of the three stages of the water supply cycle in Bahrain. The findings of benchmarking with best practices are also presented in this section.

\subsection{Energy Consumption in the Water Production Stage}

\subsubsection{Ras Abu Jarjur Plant}

Ras Abu Jarjur plant has a total of 35 major pumps that consume majority of electricity used in the plant (Table 2). Out of these pumps, there are 19 well pumps used to extract brackish groundwater from depth of $65 \mathrm{~m}$. Results of electricity consumption and specific electric energy use calculations are presented in Table 3.

\subsubsection{Sitra Power and Water Station}

The total electricity consumption was calculated based on the technical specifications of the main pumps in each of the three water desalination phases. Details of the total electricity consumption and specific electric energy use are presented in Table 4.

\subsubsection{The Al Dur Project}

There are 49 pumps in the Al Dur desalination plant. The total electricity consumption was calculated based on the pumps' technical specifications as

Table 2. Details of pumps in Ras Abu Jarjur plant [19].

\begin{tabular}{cccc}
\hline Item & Pump Type & No of pumps & Rated power $(\mathrm{kW})$ \\
\hline 1 & High pressure pumps A-H & 8 & 1200 \\
2 & High pressure pumps IandJ & 2 & 1050 \\
3 & Product transfer pump & 6 & 380 \\
4 & Well Pumps & 19 & 90 \\
\hline
\end{tabular}


Table 3. Specific electric energy use in Ras Abu Jarjur.

\begin{tabular}{cc}
\hline Indicator & Result \\
\hline Total electricityuse $(\mathrm{kWh} /$ day $)$ & 376,560 \\
Gross water production $\left(\mathrm{m}^{3} /\right.$ day $)$ & 72,360 \\
Specific electric energy use $\left(\mathrm{kWh} / \mathrm{m}^{3}\right)$ & 5.2 \\
\hline
\end{tabular}

Table 4. Specific electric energy use of Sitra by phases [18].

\begin{tabular}{ccc}
\hline Phases & Total electricityuse $(\mathrm{kWh})$ & Quantity of water/phase $\left(\mathrm{m}^{3}\right)$ \\
\hline Phase 1 & 66,061 & 22,730 \\
Phase 2 & 132,720 & 22,730 \\
Phase 3 & 410,400 & 68,191 \\
Total & 609,181 & 113,652 \\
\multicolumn{2}{c}{ Specific electric energy use $\left(\mathrm{kWh} / \mathrm{m}^{3}\right)$} & 5.3 \\
\hline
\end{tabular}

illustrated in Table 5. Accordingly, and using the amount of water produced, the specific electric energy use was calculated as presented in Table 6.

\subsubsection{The Hidd Power Company}

Similar to the calculation procedure followed above, the total electricity consumption was calculated for the Hidd plant (Table 7).

\subsubsection{ALBA Desalination Plant}

To identify the amount of electricity consumed in ALBA water desalination plant, electricity bills were retrieved for the period from January to July 2017. Total electricity consumption for water desalination and specific electric energy use are illustrated in Table 8.

\subsection{Energy Consumption in the Water Transmission Stage}

The power capacities of pumps in 27 transmission stations were used to calculate the electricity consumption in the water transmission network in Bahrain. Details of the calculation along with the results are presented in Table 9.

\subsection{Energy Consumption in the Water Distribution Stage}

Out of the six working distribution pumping stations in Bahrain, only four were accessible. Results of measurements of the voltage and current of pumps in these stations are depicted in Table 10 and Table 11. Using equations number 1 and 2 , the total electricity consumption in the water distribution network in Bahrain was calculated (Table 12).

The quantity of water being pumped in the water distribution network was obtained by solving equation number 3 . The quantity of water ranges between $27,480 \mathrm{~m}^{3} /$ month and $54,966 \mathrm{~m}^{3} /$ month. This results in specific electric energy use ranging between 0.4 and $0.9 \mathrm{kWh} / \mathrm{m}^{3}$ for the water distribution stage in $\mathrm{Ba}$ hrain. 
Table 5. Energy consumed in pumps of Al Dur plant.

\begin{tabular}{ccccc}
\hline No. & Pumps type & Quantity & $\begin{array}{c}\text { Rated powerby unit } \\
(\mathbf{M W})\end{array}$ & $\begin{array}{c}\text { Rated power for all units } \\
(\text { MW) }\end{array}$ \\
\hline 1 & High pressure pumps & 25 & 1.4 & 35 \\
2 & Booster pumps & 12 & 0.6 & 7.5 \\
3 & Clarifiers pumps & 8 & 0.7 & 5.6 \\
4 & Permeate Pumps & 4 & 0.3 & 1.2 \\
& & Total & & 49.3 \\
\hline
\end{tabular}

Table 6. Specific electric energy use in Al Dur plant.

\begin{tabular}{cc}
\hline Indicator & Result \\
\hline Total electricity consumption $(\mathrm{kWh} /$ day $)$ & $1,184,640$ \\
Gross water production $\left(\mathrm{m}^{3} /\right.$ day $)$ & 218,208 \\
Specific electric energy use $\left(\mathrm{kWh} / \mathrm{m}^{3}\right)$ & 5.4 \\
\hline
\end{tabular}

Table 7. Total energy consumption in the Hidd plant.

\begin{tabular}{cccc}
\hline Phase & $\begin{array}{c}\text { Total electricity use } \\
(\mathrm{kWh} / \text { day })\end{array}$ & $\begin{array}{c}\text { Water production } \\
\left(\mathrm{m}^{3} / \text { day }\right)\end{array}$ & $\begin{array}{c}\text { Specific electric energy use } \\
\left(\mathrm{kWh} / \mathrm{m}^{3}\right)\end{array}$ \\
\hline Phase 1 (MSF units) & 528,000 & 136,368 & 3.8 \\
Phase 3 (MED units) & 716,755 & 272,760 & 2.6 \\
\hline
\end{tabular}

Table 8. Total electricity consumption in ALBA desalination plant.

\begin{tabular}{cccc}
\hline $\begin{array}{c}\text { Month of the } \\
\text { year 2017 }\end{array}$ & $\begin{array}{c}\text { Electricity use in } \\
\text { desalination }(\mathrm{kWh} / \text { month })\end{array}$ & $\begin{array}{c}\text { Water production } \\
\left(\mathrm{m}^{3} / \mathrm{month}\right)\end{array}$ & $\begin{array}{c}\text { Specific electric energy use } \\
\left(\mathbf{k W h} / \mathrm{m}^{3}\right)\end{array}$ \\
\hline January & $3,825,600$ & $1,338,821$ & 2.8 \\
February & $3,268,320$ & $1,209,258$ & 2.7 \\
March & $3,454,560$ & $1,338,821$ & 2.5 \\
April & $3,848,640$ & $1,295,634$ & 2.9 \\
May & $2,664,960$ & $1,338,821$ & 2.0 \\
June & $3,403,680$ & $1,295,634$ & 2.6 \\
July & $3,711,840$ & $1,338,821$ & 2.7 \\
& Average specific electric energy use & 2.6 \\
\hline
\end{tabular}

Note: water production figures were assumed based on the design capacity production of 9.5 MGPD (Table 1).

\subsection{Comparison with Best Practices in the World}

Results show that the water production stage consumes around $97 \%$ of the total electricity consumption in the water supply cycle in Bahrain followed by water transmission and water distribution with $2.9 \%$ and $0.1 \%$, respectively (Figure 7).

Comparisons of water desalination-related electricity use in Bahrain were conducted with regards to best practices in the world. Results show that specific 
Table 9. Total electricity consumption in water transmission in Bahrain.

\begin{tabular}{cc}
\hline Indicator & Result \\
\hline Total power capacity of pumps $(\mathrm{kW})$ & 36,578 \\
Total electricity consumption $(\mathrm{kWh} / \mathrm{month})$ & $26,336,160$ \\
Gross water production $\left(\mathrm{m}^{3} / \mathrm{month}\right)$ & $25,776,330$ \\
Specific electric energy use $\left(\mathrm{kWh} / \mathrm{m}^{3}\right)$ & 1.0 \\
\hline
\end{tabular}

Table 10. Voltage measurements (in volt) at the booster pumping stations.

\begin{tabular}{ccccc}
\hline Booster stations & $\begin{array}{c}\text { Pumping } \\
\text { station 1 }\end{array}$ & $\begin{array}{c}\text { Pumping } \\
\text { station 2 }\end{array}$ & $\begin{array}{c}\text { Pumping } \\
\text { station 3 }\end{array}$ & $\begin{array}{c}\text { Pumping } \\
\text { station 4 }\end{array}$ \\
\hline No of pumps in each station & 2 & 2 & 2 & 2 \\
Working hours of pump 1 (h) & 12 & 12 & 12 & 14 \\
Working hours of pump 2 (h) & 12 & 12 & 12 & 8 \\
Pressure - inlet (bar) & 1.5 & 1.2 & 1.1 & 0.8 \\
Pressure - outlet (bar) & 2 & 1.2 & 1.3 & 3 \\
Difference pressure (bar) & 0.5 & 0 & 0.2 & 2.2 \\
Voltage R-Y & 401 & 401 & 389 & 404 \\
Voltage Y-B & 403 & 403 & 391 & 404 \\
Voltage B-R & 404 & 403 & 391 & 401 \\
Voltage R-N & 234 & 231 & 224 & 231 \\
Voltage Y-N & 234 & 232 & 224 & 233 \\
Voltage B-N & 235 & 232 & 227 & 232 \\
\hline
\end{tabular}

Table 11. Current measurements (in ampere) at the booster pumping stations.

\begin{tabular}{lccccc}
\hline \multirow{2}{*}{ Booster Stations } & Pumps & \multicolumn{3}{c}{ Current (Ampere) } & \multirow{2}{*}{ Average } \\
\cline { 3 - 5 } & & Phase 1 & Phase 2 & Phase 3 & \\
\hline \multirow{2}{*}{ Pumping station 1 } & Pump 1 & 18.9 & 16.9 & 18 & 17.9 \\
& Pump 2 & 19 & 17.7 & 18 & 18.2 \\
Pumping station 2 & Pump 1 & 20 & 18 & 19 & 19 \\
& Pump 2 & 21 & 19 & 19 & 19.6 \\
Pumping station 3 & Pump 1 & 16 & 15 & 15 & 15.3 \\
& Pump 2 & 19 & 17 & 19 & 18.3 \\
Pumping station 4 & Pump 1 & 21 & 20 & 22 & 21 \\
& Pump 2 & 17 & 17 & 18 & 17.3 \\
\hline
\end{tabular}

electric energy use in the five desalination plants in Bahrain exceeds that in the world based on the water desalination technology used [2] (Table 13). However, electricity used to produce water in Al Dur and Ras Abu Jarjur plants falls below the upper level of water desalination practices according to [21] and [10]; the later benchmarks are out of date, though. 
Table 12. Total electricity use in water distribution pumping stations in Bahrain.

\begin{tabular}{cc}
\hline Booster Stations & Total electricity use $(\mathrm{kWh} / \mathrm{month})$ \\
\hline Pumping station 1 & 5237 \\
Pumping station 2 & 5630 \\
Pumping station 3 & 4717 \\
Pumping station 4 & 11,113 \\
Total electric energy consumption (kWh/month) & 26,698 \\
\hline
\end{tabular}

Table 13. Specific electric energy use in water desalination plants in Bahrain compared to selected benchmarks.

\begin{tabular}{cccccc}
\hline $\begin{array}{c}\text { Desalination } \\
\text { technology }\end{array}$ & $\begin{array}{c}\text { Desalination } \\
\text { plant }\end{array}$ & $\begin{array}{c}\text { Specific electric energy } \\
\text { use }\left(\mathrm{kWh} / \mathrm{m}^{3}\right)\end{array}$ & $(2)$ & (21) & (10) \\
\hline SWRO & Al Dur & 5.4 & $3.0-4.0$ & $4.0-6.0$ & - \\
MED & ALBA & 2.6 & & & \\
& Al Hidd & 2.6 & $1.5-2.5$ & $2.0-2.5$ & $1.2-2.5$ \\
MSF & Al Hidd & 3.8 & & & \\
& Sitra & 5.3 & $2.5-4.0$ & $2.5-5.0$ & $3.0-5.0$ \\
RO & Ras Abu Jarjur & 5.2 & $0.5-2.5$ & - & $2.5-7.0$ \\
\hline
\end{tabular}

Notes: SWRO means Reverse Osmosis using Sea Water, MED means Multi-Effect Distillation, MSF means Multi-Stage Flashing, RO means Reverse Osmosis.

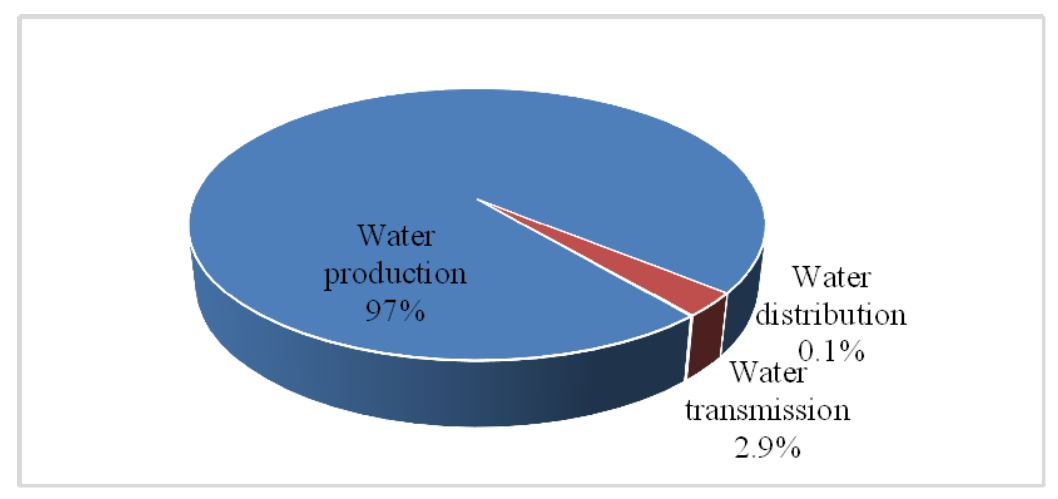

Figure 7. Electricity consumption in the water supply cycle in Bahrain.

Nevertheless, water desalination plants that use the MED desalination technology appear to be more energy efficient compared to other plants that adopt MSF or RO technologies. This result is consistent with that in relevant literature [2] [10] [21].

\section{Conclusions}

The amount of energy used in the water supply cycle in Bahrainis quantified. The results showed that the majority of the water-related electricity use was associated with the water production stage, specifically water desalination. Furthermore, comparisons with global best practices in water desalination revealed 
that the water desalination practices in Bahrain can be considered as highly energy-intensive. This suggests a large potential for improving energy efficiency in water desalination plants with particular emphasis on those using MSF and RO technologies. Enhancing energy efficiency in water desalination plants can be achieved by improving the operation and maintenance procedures. Electricity meters can be installed in site to monitor progress towards achieving energy efficiency targets. There is also a potential for energy savings in the water distribution stage. Although the share of this stage of the total energy consumption is minimal, enhancing energy efficiency can be achieved through the replacement of the old pumps.

Despite the efforts made in this study to provide bottom-up collected data for the water-related energy use in Bahrain, this work has some limitations. First, almost all of the calculations were based on the technical specifications of the equipment and not the actual energy consumption. Moreover, some assumptions related to the working hours of the main energy consumers were made resulting in some uncertainty in the findings. Furthermore, only major electricity consumers were considered. Nonetheless, the quantification of the water-related energy use in this paper is carried out for the first time for Bahrain. The results from this study can provide a baseline for future studies and comparisons. It can also provide guidance towards achieving energy efficiency in the water sector through focusing on the main energy consumer, i.e., water desalination plants, and can also inform the selection of desalination technologies in future plants, and can aid in formulating the energy related parts in future contracts with the private sector.

It is recommended to quantify the thermal energy in the MSF and MED plants in Bahrain ${ }^{1}$. It is also imperative to pay special attention to the reactive energy consumption of the different pumping stations where improving the power factor to 0.9 needs to be set as a target. Moreover, it is vital for decision making to explore the water-related energy use in the wastewater treatment sector to provide a holistic overview of the energy input in the whole urban water cycle in Bahrain.

\section{Acknowledgements}

The authors would like to thank the Electricity and Water Authority in Bahrain for data provision. The authors would also like to extend their thanks to the operators in the private sector-owned water desalination plants in Bahrain for collaboration.

\section{References}

[1] Hardy, L., Garrido, A. and Juana, L. (2012) Evaluation of Spain's Water-Energy Nexus. International Journal of Water Resources Development, 28, 151-170. https://doi.org/10.1080/07900627.2012.642240

${ }^{1}$ Byfollowing the methodology explained in [22] [23] [24]. 
[2] ESCWA (2017) Developing the Capacity of ESCWA Member Countries to Address the Water and Energy Nexus for Achieving Sustainable Development Goals: Water-Energy Nexus Operational Toolkit-Resource Efficiency Module. UN, Beirut.

[3] Napoli, C. and Garcia-Tellez, B. (2016) A Framework for Understanding Energy for Water. International Journal of Water Resources Development, 32, 339-361. https://doi.org/10.1080/07900627.2015.1122579

[4] Al-Mutrafi, H., Al-Zubari, W., El-Sadek, A. and Gelil, I.A. (2018) Assessment of the Water-Energy Nexus in the Municipal Water Sector in Eastern Province, Saudi Arabia. Computational Water, Energy, and Environmental Engineering, 07, 1-26. https://doi.org/10.4236/cweee.2018.71001

[5] Granit, J., Jägerskog, A., Lindström, A., Björklund, G., Bullock, A., Löfgren, R., et al. (2012) Regional Options for Addressing the Water, Energy and Food Nexus in Central Asia and the Aral Sea Basin. International Journal of Water Resources Development, 28, 419-432. https://doi.org/10.1080/07900627.2012.684307

[6] Scott, C.A., Pierce, S.A., Pasqualetti, M.J., Jones, A.L., Montz, B.E. and Hoover, J.H. (2011) Policy and Institutional Dimensions of the Water-Energy Nexus. Energy Policy, 39, 6622-6630. https://doi.org/10.1016/j.enpol.2011.08.013

[7] Raluy, R.G., Serra, L., Uche, J. and Valero, A. (2004) Life-Cycle Assessment of Desalination Technologies Integrated with Energy Production Systems. Desalination, 167, 445-458. https://doi.org/10.1016/j.desal.2004.06.160

[8] Khawaji, A.D., Kutubkhanah, I.K. and Wie, J.-M. (2008) Advances in Seawater Desalination Technologies. Desalination, 221, 47-69.

https://doi.org/10.1016/j.desal.2007.01.067

[9] Raluy, G., Serra, L. and Uche, J. (2006) Life Cycle Assessment of MSF, MED and RO Desalination Technologies. Energy, 31, 2361-2372. https://doi.org/10.1016/j.energy.2006.02.005

[10] Siddiqi, A. and Anadon, L.D. (2011) The Water-Energy Nexus in Middle East and North Africa. Energy Policy, 39, 4529-4540. https://doi.org/10.1016/j.enpol.2011.04.023

[11] Guyer, J. (2012) Introduction to Pumping Stations for Water Supply Systems. https://www.sswm.info/sites/default/files/reference_attachments/GUYER\%202012 \%20Introduction\%20to\%20Pumping\%20Stations\%20for\%20Water\%20Supply\%20S ystems.pdf

[12] Sarbu, I. and Borza, I. (1998) Energetic Optimization of Water Pumping in Distribution Systems. Periodica Polytechnica Mechanical Engineering, 42, 141-152.

[13] Vieira, F. and Ramos, H.M. (2009) Optimization of Operational Planning for Wind/Hydro Hybrid Water Supply Systems. Renewable Energy, 34, 928-936. https://doi.org/10.1016/j.renene.2008.05.031

[14] Al-Zubari, W. (2014) The Costs of Municipal Water Supply in Bahrain. Chatham House, the Royal Institute of International Affairs, London.

[15] Al-Zubari, W., Al-Turbak, A., Zahid, W., Al-Ruwis, K., Al-Tkhais, A., Al-Muataz, I., et al. (2017) An Overview of the GCC Unified Water Strategy (2016-2035). Desalination and Water Treatment, 81, 1-18. https://doi.org/10.5004/dwt.2017.20864

[16] IEA (2017) Key World Energy Statistics. IEA, Paris.

[17] Copeland, C. and Carter, N. (2017) Energy-Water Nexus: The Water Sector's Energy Use. Congressional Research Service.

[18] EWA (2017) Sitra Power and Water Station. http://www.ewa.bh/en/Media/Publications/Publication/sitra\%20-\%20booklet.pdf 
[19] EWA (2017) Ras Abu JarJur BWRO Desalination Plant. http://www.ewa.bh/en/Media/Publications/Publication/abu\%20jerjoor-booklet.pdf

[20] HPC (2009) Hidd Power Company. http://hpc.com.bh/default.asp

[21] Shahzad, M.W., Burhan, M., Ang, L. and Ng, K.C. (2017) Energy-Water-Environment Nexus Underpinning Future Desalination Sustainability. Desalination, 413, 52-64. https://doi.org/10.1016/j.desal.2017.03.009

[22] Najafi, B., Shirazi, A., Aminyavari, M., Rinaldi, F. and Taylor, R.A. (2014) Exergetic, Economic and Environmental Analyses and Multi-Objective Optimization of an SOFC-Gas Turbine Hybrid Cycle Coupled with an MSF Desalination System. Desalination, 334, 46-59. https://doi.org/10.1016/j.desal.2013.11.039

[23] Safarian, S. and Aramoun, F. (2015) Energy and Exergy Assessments of Modified Organic Rankine Cycles (ORCs). Energy Reports, 1, 1-7. https://doi.org/10.1016/j.egyr.2014.10.003

[24] López Paniagua, I., Rodríguez Martín, J., González Fernandez, C., Jiménez Alvaro, Á. and Nieto Carlier, R. (2013) A New Simple Method for Estimating Exergy Destruction in Heat Exchangers. Entropy, 15, 474-489.

https://doi.org/10.3390/e15020474 